\title{
M-El Regimen
}

National Cancer Institute

\section{Source}

National Cancer Institute. M-El Regimen. NCI Thesaurus. Code C9601.

A chemotherapy regimen consisting of methotrexate, etoposide, and ifosfamide that may be used in the treatment of osteosarcoma. 